て遮水し, 同年 8 月 $106 \mathrm{~m}$ の掘下工事を完成した。同山 ではその後の坑道掘進涌水に対しても，ハイドロック工 法を行つて扔り，槙峰に於てもセメント乃至ハイドロッ クグラウチング工法を採用している。

\section{3. 斜坑開さく}

戦後の斜坑開さくは24年頃より漸増し，30年には最高 着工数を示した。斜坑は鉱脈鉱床に於ては脈沿いのもの が多く, 大部分 50〜 $80^{\circ}$ の急傾斜であり, 塊状及びキー スラーガー鉱床では総て $50^{\circ}$ 以下の緩傾斜である。開さ く方式は掘下りによるものが多いが，その傾斜や加背等 に変化が多いので比較的機械化が遅れ, ズリ積は人力, 巻上げはスキップによるものが多い。昭和31年着工した 生野のコンベヤ斜坑（全長 $530 \mathrm{~m}$, 傾斜 $16^{\circ} 37^{\prime}$ ) では引立 から約 $100 \mathrm{~m}$ 間はスクレーパ搔を行い，中継運搬として 容量 $1.1 \mathrm{~m}^{3}$ のゴムタイヤ付木製鈗車で巻下げた。又同年 楨峰に於てスラシヤ・ランプを採用, 昭和 33 年10月着工 した飯盛釷山新斜坑（全長 $717 \mathrm{~m}$, 傾斜 $18^{\circ}, 2.3 \times 3.0 \mathrm{~m}$ 加背掘上り, 下り) 開さくには 4 車積スクレープローダ 一を使用して, 掘下りでは 1 日当 $1.58 \mathrm{~m}$, 掘上りでは $1.28 \mathrm{~m}$ の成績をえた。

今後は輸送合理化工事に伴う連絡坑又はベルト坑とし ての緩傾斜斜坑開さく工事が多くなるものと思わ机る。

\section{4. 掘上り}

掘上り開さくは鉣床開発，採掘準備，運搬，通気等に 大きな役割を果し，作業も比較的困難であるにもかかわ らず，近年まで改善の跡は極めて少なかつた。しかし開 さく機器の改善に引続き坑道掘進, 掘下りの機械化が進 行し，また諸外国に扔ける特殊開さく法（例えば導孔と 吊りケージによる方法, 試錐孔による一時爆破法, 特殊 足場を用いる方法，全断面開さく機等）の紹介に刺激さ れ，昭和 30 年頃より生野その他において古レール等を利 用七た伸縮足場が使用され，また34年豊羽においては押 上気筒に足場をつけ圧気によつて仮足場を押上げる方式 をとつて工程の上昇を計つた。また同年末にはスェーデ ン・アリマック社のレイズ・クライマーを柵原・別子で 購入し，掘上り法の改善に一転機を作つた。

柵原に抢いては STH-3 型により L 27〜30 間 45mの 内 $30 \mathrm{~m}$ を掘上つた。穿孔はオフセットストーパによるバ ーンカットーぐーンホール径 $70 \mathrm{~mm}$, 他の 17 本は $40 \mathrm{~m} \mathrm{~m}$ 径) 方式で孔梁 1.8 2.2m, 第1方第孔発破, 第 2 方ガ イドレール延長, 浮石落し, 第 3 方ズリ積 (ローダー) を行い，1発破掘進長 $1.74 \mathrm{~m}, \mathrm{~m}$ 当経費は従来の支柱掘 上り 27,800 円に対し 17,000 円（償却を含まない）, 同工 数16.91工に対し 7.00工 の成績をえた。

掘上り作業の重要性に鑑み今後あらゆる方式を検討し て益々改善される事が切望される。

\section{採}

\section{掘}

酒 并健 次
金子正 男
江 端 清

採掘法は, 鉱床の形態, 規模, 鉣質, 母岩の性質など, それぞれの鉱山の特殊性によつてきまるものであり,一 般には変化の少ないものであるが，第二次世界大戦を契 機として, 戦前戦後を比較すると相当の進歩をもたらし ている。すなわち昭和22〜23年頃から次々と海外の新ら しい技術が紹介導入され，昭和 27 年以降はそれらの新技 術がそれぞれの現場条件に適するように，消化吸収され て, 採掘法の合理化が著しく促進されている。この合理 化に直接影響のあつたと思われる技術を 2,3 のべてみる と次の通りである。

（1）長孔発破 22 年神岡鉱山で長孔発破によるサ ブレベル採掘法が本格的に実施に移された。タングステ ン゙カーバイドビットの実用化, MS 電気雷管の併用によ つてその効果は一層認識され, 半長孔発破も案出された。 最近は軟弱な岩質の釷山でも応用されるようになつた。

（2）切羽運搬の機械化 戦前にもローダは一部で 使用されていたが，戦後はその使用が一般化された。ス クレーパについては 22 年頃から研究が始められ, その後 は遠隔操作方式の採用などにより，採掘切羽に和ける鉱， 石または充填物の運搬に広く使用されている。また土木 関係で使用を始めたポータブルコンベヤも切羽で使用さ れるよらになり, 戦前の手積が主体であつた切羽運搬は 著しく機械化されるようになつた。

（3）選釷廃さいの坑内充填 27年からわが国でも 選鉱廃さいの坑内充填による採掘作業が日立釷山で開始 された。浮選廃さいの処理には常に面倒な問題を伴つて いるが，この技術の採用によつて一石二鳥の効果をあげ ている鉱山が多い。

（4）その他 ルーフボルト鉄柱及びカッペ, タン グステンガーバイドビット，MS電気雷管，エヤレッグ 付ドリル等の使用が発破法の改善と相俟つて採掘法の合 理化没役立つている。

採掘法の変遷と作業工程の変化については鉱床の種類 別によつてのベてみよう。

まず塊状銀床についてみると，更にこれを，接触交代 鉱床, 黒釷及び硫黄鉱床に分けてみると次のような変遷 進歩がある。

\section{1. 接触交代鉱床}

一般江岩質の堅硬な塊状鉱床で，従来の主要な採掘法 であつたシニリンケージ法から長孔発破，久クレパなど による機械積込み,ルーフボルテングの採用などによる 
第 5 表接触交代鉱床

\begin{tabular}{|c|c|c|c|c|c|c|c|c|c|c|c|}
\hline \multirow{2}{*}{ 釷山名 } & \multicolumn{2}{|c|}{ 主要な採掘法の変遷 } & \multirow{2}{*}{ 導入技琎 } & \multirow{2}{*}{\multicolumn{2}{|c|}{$\begin{array}{l}\text { 全山出鉣量 } \\
\text { (年度) }\end{array}$}} & \multirow{2}{*}{$\begin{array}{ll}\text { 粗 } & \text { 鉣 } \\
\text { 過 } & \text { 去 }\end{array}$} & \multirow{2}{*}{$\frac{\text { 品 }}{\text { 現 }}$} & \multirow{2}{*}{$\begin{array}{l}\text { 位 } \\
\text { 在 }\end{array}$} & \multicolumn{2}{|c|}{$\begin{array}{l}\text { 坑内 } 1 \text { 人当 } 0 \\
\text { 出 珤 }\end{array}$} & \multirow{2}{*}{ 備 } \\
\hline & 過 去 & 在 & & & & & & & 過 去 & 現 在 & \\
\hline 釜 石 & 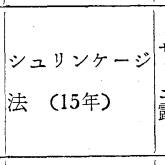 & 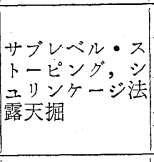 & $\begin{array}{l}\text { 長 孔 発 破 } \\
\text { 切羽運搬機械化 } \\
\text { M S 発 破 }\end{array}$ & $\begin{array}{l}15 \text { 年 } \\
21 \text { 年 } \\
\text { 現在 }\end{array}$ & \begin{tabular}{r|}
$\mathrm{t} /$ 日 \\
1,618 \\
1,042 \\
$4,5 \subseteq 0$
\end{tabular} & $\begin{array}{c}\text { 鉄鉱 } \mathrm{Fe} 46.3 \\
\text { (15年) }\end{array}$ & 鉄銅鉱 & $\begin{array}{r}\mathrm{Fe} 22.6 \\
\mathrm{Cu} 0.73\end{array}$ & $\begin{array}{c}t / 1 \\
5.9 \\
\text { (15年) }\end{array}$ & $\begin{array}{c}i t / \text { 日 } \\
8.7\end{array}$ & 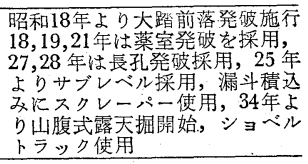 \\
\hline 秩 父 & $\begin{array}{l}\text { シュリンケー } \\
\text { 法 (15年) }\end{array}$ & 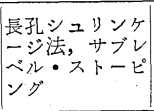 & $\begin{array}{llll}\text { 長 } & \text { 孔 } & \text { 発 } & \text { 破 } \\
M & S & \text { 発 } & \text { 破 }\end{array}$ & $\begin{array}{l}15 \text { 年 } \\
21 \text { 年 } \\
\text { 年在 }\end{array}$ & $\begin{array}{r}t / \text { /月 } \\
5,200 \\
2,700 \\
14,000\end{array}$ & 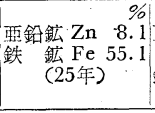 & 要鉊鉈 & 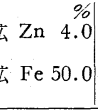 & $\begin{array}{c}\mathbf{t} / \text { 月 } \\
23.1 \\
(25 \text { 年 })\end{array}$ & $\begin{array}{c}t / \text { 月 } \\
65.0\end{array}$ & $\begin{array}{l}\text { 昭和12年よりさく岩機使用，25 } \\
\text { 年上向さく孔を水平長孔さくく } \\
\text { に改も }\end{array}$ \\
\hline $\begin{array}{l}\text { 神 岡 } \\
\text { (榞洞) }\end{array}$ & $\mid \begin{array}{cc}\text { 空 } & \text { 洞 掘 } \\
& \text { (10年) }\end{array}$ & 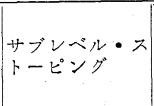 & $\begin{array}{l}\text { 長势羽運搬機械化 } \\
\mathrm{M} \text { 破 }\end{array}$ & $\begin{array}{l}\text { 芰 } 10 \text { 算 } \\
21 \text { 年 } \\
\text { 年在 }\end{array}$ & $\begin{aligned} t / / 月 \\
17,228 \\
16,664 \\
75,000\end{aligned}$ & $\begin{array}{cc}\mathrm{Pb} & 1.0 \\
\mathrm{Zn} & 6.5 \\
(10 \text { 年 })\end{array}$ & $\begin{array}{l}\mathrm{Pb} \\
\mathrm{Zn}\end{array}$ & $\begin{array}{l}0.5 \\
4.0\end{array}$ & $\begin{array}{c}t / \text { 日 } \\
2.3\end{array}$ & $\begin{array}{c}t / \text { 日 } \\
5.1\end{array}$ & $\begin{array}{l}\text { 照和 } 12 \text { 17年斜面横执採掘法採 } \\
\text { 用(試験的), } 22 \text { 年よりサプ } \\
\text { ルに切替着手 }\end{array}$ \\
\hline $\begin{array}{l}\text { 神 岡 } \\
\text { (茂住) }\end{array}$ & $\mid \begin{array}{c}\text { 充 填 採 掘 } \\
\text { (10年) }\end{array}$ & 充 填 採 掘 & 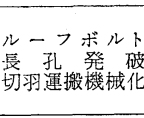 & $\begin{array}{l}10 \text { 年 } \\
\text { 文 } 21 \text { 年 } \\
\text { 琴在 }\end{array}$ & $\begin{array}{r}\mathrm{t} / \text { 月 } \\
2,500 \\
3,000 \\
15,000\end{array}$ & $\begin{array}{cc}\mathrm{Pb} & 8.0 \\
\mathrm{Zn} & 12.0 \\
(10 \text { 年 })\end{array}$ & & $\begin{array}{l}2.3 \\
7.9\end{array}$ & $\begin{array}{c}\mathrm{t} / \mathrm{日} \\
1.0\end{array}$ & $\begin{array}{c}\mathrm{t} / \text { 㔭 } \\
2.5\end{array}$ & 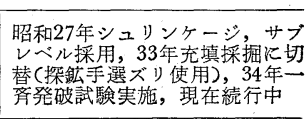 \\
\hline 中 竜 & $\mid \begin{array}{l}シ \text { シンケージ } \\
\text { 法 (10年) }\end{array}$ & 充 填 採 掘 & & $\begin{array}{l}30 \text { 年 } \\
\text { 現在 }\end{array}$ & $\begin{array}{l}10,332 \\
15,400\end{array}$ & $\begin{array}{|cc|}\mathrm{Pb} & 0.6 \\
\mathrm{Zn} & 5.5 \\
\text { (30年) }\end{array}$ & & $\begin{array}{l}\% \% \\
0.7 \\
5.3\end{array}$ & & & $\begin{array}{l}\text { 昭和 } 9 \text { 年開山，24年休山，26年 } \\
\text { 再開，充填採掘法を採用 }\end{array}$ \\
\hline
\end{tabular}

第 6 表黑鉱及。゙硫黄鉱床

\begin{tabular}{|c|c|c|c|c|c|c|c|c|c|c|}
\hline \multirow{2}{*}{ 鉿山名 } & \multicolumn{2}{|c|}{ 主要な採掘法の変遷 } & \multirow{2}{*}{ 導入技術 } & \multirow{2}{*}{$\begin{array}{l}\text { 全山出鉱量 } \\
\text { (年度) }\end{array}$} & \multirow{2}{*}{$\begin{array}{cc}\text { 粗 } & \text { 鉱 } \\
\text { 過 } & \text { 去 } \\
\end{array}$} & \multirow{2}{*}{$\begin{array}{c}\text { 品 } \\
\text { 現 }\end{array}$} & \multirow{2}{*}{$\begin{array}{l}\text { 位 } \\
\text { 在 }\end{array}$} & \multicolumn{2}{|c|}{$\begin{array}{l}\text { 切羽 } 1 \text { 人当量 } \\
\text { 出 }\end{array}$} & \multirow{2}{*}{ 備 } \\
\hline & 過去 & 在 & & & & & & 過 去 & 現 在 & \\
\hline 花 岡 & $\begin{array}{c}\text { ケービング法 } \\
\text { (10年) }\end{array}$ & 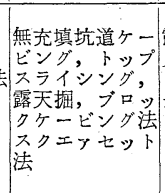 & 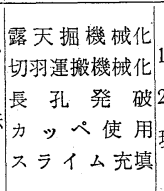 & $\begin{array}{rr}\text { t/月 } \\
10 \text { 年 } & 20,880 \\
21 \text { 年 } & 8,049 \\
\text { 現在 } & 42,295\end{array}$ & $\begin{array}{c}\mathrm{Cu} \quad 2.9 \\
\text { (10年) }\end{array}$ & $\mathrm{Cu}$ & $\begin{array}{l}\% \\
1.8 \\
34.6\end{array}$ & $\begin{array}{c}\mathbf{t} / \text { 月 } \\
24 \\
\text { (10年) }\end{array}$ & $\begin{array}{c}t / \text { 月 } \\
51.8\end{array}$ & 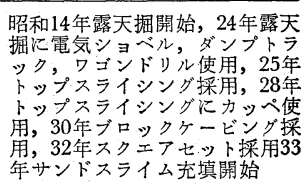 \\
\hline 花 輪 & $\begin{array}{l}\text { 手掘差切掘進引 } \\
\text { 抜 (10年) }\end{array}$ & 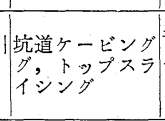 & $\mid \begin{array}{l}\text { 半 長 孔 発 破 } \\
\mid \\
\text { カ切羽運搬機械化 } \\
\text { カ }\end{array}$ & $\begin{array}{r}1 \\
t / 6 \\
45 \\
38 \\
387\end{array}$ & 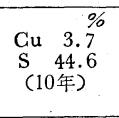 & $\begin{array}{l}\mathrm{Cu} \\
\mathrm{S} \\
\mathrm{Zn}\end{array}$ & $\begin{array}{c}\% \\
0.8 \\
27.1 \\
0.5\end{array}$ & $\begin{array}{c}\text { t/㔭 } \\
0.6 \\
(12 \text { 年 })\end{array}$ & $\begin{array}{c}\mathbf{t} / \text { 日 } \\
2.2\end{array}$ & 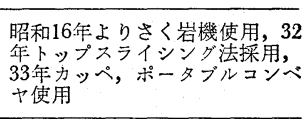 \\
\hline 松 尾 & 柱 $\begin{array}{c}\text { 房 } \\
\text { (10年) }\end{array}$ & 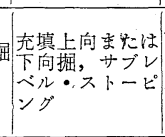 & 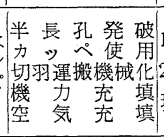 & 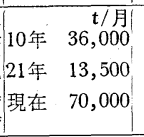 & $\begin{array}{l}\mathrm{S} \quad 38.0 \\
\text { (10年) }\end{array}$ & S & $\begin{array}{l}\% \\
33.0\end{array}$ & $\left|\begin{array}{c}t / \text { 日 } \\
5 \\
\text { (10年) }\end{array}\right|$ & $\begin{array}{l}t / \text { 㔭 } \\
12\end{array}$ & 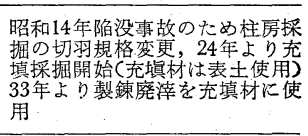 \\
\hline
\end{tabular}

サブレベル採掘法が主体になつてきている。特殊な例と しては，全石鉱山における大発破があげられる。一部で はシュリンケージ採掘法は戦後充填採鉱に変つてきてい る。わが国の主要な接触交代鉱床についてその採掘法の 変化と作業工程の増大を示すと第 5 表の通りである。

\section{2. 黑鉱及び硫黄鉱床}

本鉱床の特徴は母岩が一般に軟弱なことで, 他の塊状 鉱床特に接触交代鉱床とは異なり，ケービング法が主と して採用されているが，とくに戦後はこれに著しい改良 が加えられた。すなわち戦前の柱房法は戦後は充塡採掘 に変り, ケービング法にはカッペが使用され，ポータブ ルコンベヤも使つて極力機械化するようになつた。わが 国の2〜3の黒鉱及び硫黄鉱床について, その採掘法の変 遷と作業工程を示せば第 6 表の通りである。

塊状鉱床に似ているが, 少し違うものとして層状含銅 琉化鉄鉱及びその類似鉱床がある。この種の鉱床はその
規模や形態に著るしい差異があり, 大規模鉱床は，むし ろ塊状鉱床と考えてよく，岩質は接触交代鉱床よりもや や軟弱な場合が多い。したがつて採掘法からみれば，各 鈗山の特徴によつて大きな差異が認められる。キースラ 一ガでは, 戦前, 無充填採掘をやつていた鉱山では充寚 採掘法に変り, スライム充㙗も行つており, 切羽運搬の 機械化は例外なく行われている。また母岩の軟弱な鉱山 では黒鉱鉱床に似た採鉱法で, 戦後はカッペの使用も行 われている。柵原鉱山では戦前は残柱式上向階段充塡掘 であつたが, 戦後はカットアンドフイルやサブレベルや, さらに特長のある水平分層法が実施されている。河山鉱 山では, 戦前はシュリンケージ法や上向階段法であつた が，戦後は残柱下向法や，セメントモルタルを使用する 充垻法を実施している。わが国のこの種釷床の採釷法の 変遷や作業工程を例示すれば次の通りである。（第 7 表 参照) 
第 7 表 層状含銅硫化鉄及びその類似鉣床

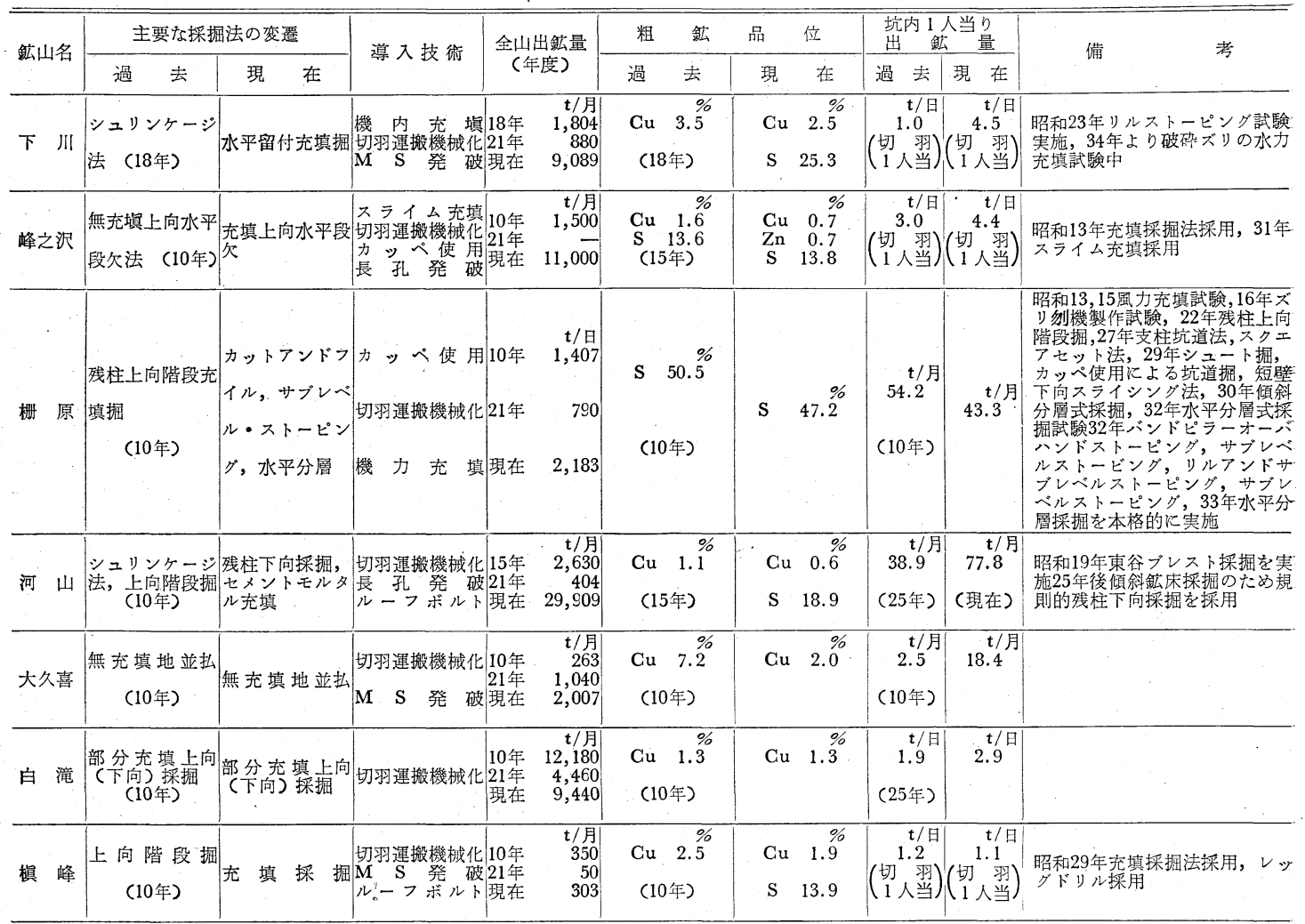

第 8 表脈 状鉱床

\begin{tabular}{|c|c|c|c|c|c|c|c|c|c|c|}
\hline \multirow{2}{*}{ 鉣山名 } & \multicolumn{2}{|c|}{ 主要な採掘法の変遷 } & \multirow{2}{*}{ 導入技術 } & \multirow{2}{*}{ 全山出鉱量 } & \multirow{2}{*}{$\begin{array}{c}\text { 粗 鉣 } \\
\text { 過 去 }\end{array}$} & \multirow{2}{*}{$\frac{\text { 品 }}{\text { 現 }}$} & \multirow{2}{*}{$\frac{\text { 位 }}{\text { 在 }}$} & \multicolumn{2}{|c|}{$\begin{array}{l}\text { 坑内 } 1 \text { 人当 } \\
\text { 出 }\end{array}$} & \multirow{2}{*}{ 備 } \\
\hline & 去 & 現 & & & & & & 過 去 & 現 在 & \\
\hline 豊 羽 & $\begin{array}{l}\text { 充填上向水平目 } \\
\text { 欠 (15年) }\end{array}$ & 欠 & 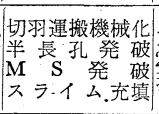 & 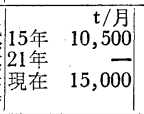 & $\begin{array}{cc}\mathrm{Pb} & 3.5 \\
\mathrm{Zn} & 8.0 \\
\mathrm{~S} & 16.0 \\
\text { (15年) }\end{array}$ & $\begin{array}{ll}\mathrm{Pb} \\
\mathrm{Zn} \\
\mathrm{S} & 1\end{array}$ & $\begin{array}{l}\% \% \\
3.0 \\
3.2 \\
15.5\end{array}$ & $\left.\mid \begin{array}{c}\mathbf{t} / \text { 日 } \\
3.0 \\
(15 \text { 年 }) \\
\left(\begin{array}{cc}\text { 珝 } \\
1\end{array} \text { 人当 }\right.\end{array}\right)$ & $\begin{array}{c}\text { t/日 } \\
5.0 \\
(\text { 切 翏 } \\
1 \text { 人当 }\end{array}$ & $\begin{array}{l}\text { 昭和 } 28 \text { 年 } \\
\text { 欠沉統一 } \\
\text { 切替 }\end{array}$ \\
\hline 阿 た & 抜 & $\begin{array}{l}\text { 抜掘, シュリン 法, 上向 } \\
\text { r } \\
\text { 階段掘 }\end{array}$ & & 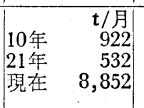 & $\begin{array}{l}\mathrm{Au} 15.6 \\
\text { (10年) }\end{array}$ & $\mathrm{Cu}$ & 1.1 & $\begin{array}{c}\mathrm{t} / \text { 日 } \\
0.6 \\
\text { (21年) }\end{array}$ & $\begin{array}{c}\mathrm{t} / \mathrm{G} \\
2.6\end{array}$ & 型 \\
\hline 高 玉 & $\mid \begin{array}{l}\text { シュリンケージ } \\
\text { 法 (10年) }\end{array}$ & $\begin{array}{l}シ ュ リ ン ケ ー ~ \\
\text { 法 }\end{array}$ & $\left|\begin{array}{cccc}M & S & \text { 発 } & \text { 破 } \\
レ ッ ク ゙ & ト ゙ リ & ル\end{array}\right|$ & 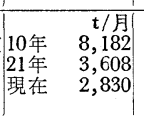 & $\begin{array}{c}\mathrm{gu} / \mathrm{t} \\
\mathrm{Au} \\
\mathrm{Ag} 7.0 \\
\text { (10年) }\end{array}$ & & $\begin{array}{l}\mathrm{g} / \mathrm{t} \\
7.9 \\
64.0\end{array}$ & 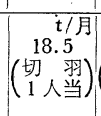 & $\left(\begin{array}{c}t / \text { 月 } \\
22.6 \\
\text { 切 } \\
1 \text { 羽 } \\
1 \text { 人当 }\end{array}\right)$ & 切替, \\
\hline 足 尾 & $\begin{array}{l}\text { シニリンケ } \\
\text { 法 (10年) }\end{array}$ & 法二 & 切羽運搬機械化 & 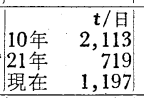 & $\begin{array}{c}\mathrm{Cu} 1.9^{\%} \\
(10 \text { 年) }\end{array}$ & $\mathrm{Cu}$ & \%ó & $\begin{array}{c}t / \text { 日 } \\
1.0 \\
\text { (10年) }\end{array}$ & $\begin{array}{c}t / \theta^{2} \\
1.3\end{array}$ & \\
\hline 持 越 & $\mid \begin{array}{c}\text { シニリンケージ } \\
\text { 法, 水平段欠 } \\
(10 \text { 年 })\end{array}$ & 充填水平段欠 & レッグドリル & $\left|\begin{array}{rr}10 \text { 年 } & \boldsymbol{t}, 000 \\
21 \text { 年 } & 300 \\
\text { 現在 } & 3,400\end{array}\right|$ & $\begin{array}{cc} & \mathrm{g} / \mathrm{t} \\
\mathrm{Au} & 7 \cdot 1 \\
\mathrm{Ag} & 215 \\
\text { (10年) } & \end{array}$ & $\begin{array}{l}\mathrm{Au} \\
\mathrm{Ag}\end{array}$ & $\begin{array}{l}\mathrm{g} / \mathrm{t} \\
9.3 \\
296\end{array}$ & $\begin{array}{r}\mathrm{t} / \text { 月 } \\
13.1 \\
\text { (10年) }\end{array}$ & 29.6 & 2採用 \\
\hline 生 野 & $\begin{array}{l}\text { シニリソケ } \\
\text { 法 (10年) }\end{array}$ & 充 填 採 掘 & $\begin{array}{l}\text { 切羽運搬機械化 } \\
ス 亏 \text { 真填 }\end{array}$ & $\begin{array}{rr}10 \text { 年 } & 21,499 \\
21 & 4,694 \\
\text { 年 } & 4, \text { 在 } \\
19,504\end{array}$ & $\begin{array}{cc}\mathrm{Cu} & 1 . \% \\
\mathrm{Zn} & 2.9 \\
(10 \text { 年 }) & \\
\end{array}$ & $\begin{array}{l}\mathrm{Cu} \\
\mathrm{Zn}\end{array}$ & $\begin{array}{l}\% \\
1.3 \\
2.3 \\
0.5 \\
\end{array}$ & $\begin{array}{c}t / \text { 月 } \\
34 \\
\text { (10年) }\end{array}$ & $\begin{array}{l}\mathrm{t} / \text { 月 } \\
35\end{array}$ & $\begin{array}{l}\text { 照和 } 28 \text { 年サンドスライ } \\
\text { 赑サ }\end{array}$ \\
\hline 明 延 & $\begin{array}{l}\text { シュリ } \\
\text { 法 C10 }\end{array}$ & 充 填 採 & $\mid \begin{array}{l}\text { 切羽運搬機械化 } \\
\text { 機 力 充 填 }\end{array}$ & $\left|\begin{array}{rr}10 \text { 年 } & 25,000 \\
21 \text { 年 } & 1,500 \\
\text { 現在 } & 22,000\end{array}\right|$ & $\begin{array}{cc}\mathrm{Cu} & 0.7^{\%} \\
\mathrm{Sn} & 0.8 \\
\text { (10年) }\end{array}$ & $\begin{array}{l}\mathrm{Cu} \\
\mathrm{Sn} \\
\mathrm{Zn}\end{array}$ & $\begin{array}{l}\% \% \\
1.2 \\
0.3 \\
2.3\end{array}$ & $\left.\mid \begin{array}{c}\mathrm{t} / \text { 日 } \\
1.4 \\
\left(\begin{array}{cc}\text { 切 } \\
1\end{array} \text { 人当 }\right.\end{array}\right)$ & $\left(\begin{array}{c}{ }^{t / 1} \\
2.3 \\
\text { 切 } \\
1 \text { 人翏 }\end{array}\right)$ & 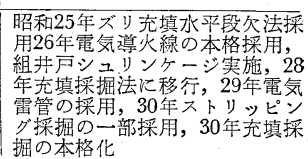 \\
\hline 対 州 & $\begin{array}{l}\text { シュリンケ } \\
\text { 法 (19年) }\end{array}$ & 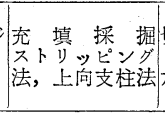 & 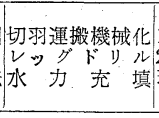 & 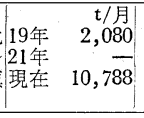 & 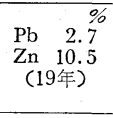 & $\begin{array}{ll}\mathrm{Pb} \\
\mathrm{Zn} \\
\mathrm{S} & 1\end{array}$ & $\begin{array}{c}\% \\
5.5 \\
7.8 \\
13.5\end{array}$ & \begin{tabular}{|c|}
$\mid t / 月$ \\
12 \\
$(19$ 年) \\
$\left(\begin{array}{cc}\text { (切 } \\
1 & \text { 人当 }\end{array}\right)$
\end{tabular} & $\left(\begin{array}{c}\mathrm{t} / \text { 月 } \\
36 \\
\left(\begin{array}{c} \\
\text { 切 } \\
1\end{array} \text { 人当 }\right.\end{array}\right)$ & 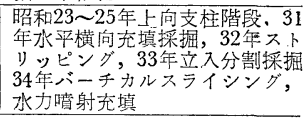 \\
\hline
\end{tabular}


次に脈状鉱床についてのべてみよう。

この種鉱床では従来低コスト採鉣法として戦前主に採 用されていたシュリンケージ法がすたれ，機械を使用し た充㙗採掘法一上変りつつ亦る傾向が認められる。その 理由は盤返りによるズリ混入, 細脈採掘に伴う品位の低 下, 採掘現場の深部移行に伴う漏気並びに通気管理の困 難化など, シュリンケージ法では解決出来ない問題があ つたためで, 戦後は廃さい充垻, スクレーパによる機械 化，レッグドリルなぞの採用により合理化が行われた。 そ狄らの採掘法の変遷と作業工程を示すと第 8 表の通り である。

以上簡単に, 戦前戦後の採掘法及びその作業工程を比 較してみたが, 今後は, 新技術の導入はもとより, 採掘 法の合理化を目指寸不断の努力によつて, 更に新らしい 淮歩した採掘法が実施されるようになるであるう。

運搬

\section{1. 緒 言}

採掘された鉱石の運搬, 作業に必要な材料, 機械など の搬出入および人員の昇降等,鉱山における運搬作業法, 坑内作業の大部分を占めており極めて重要なものであ る。

このことは戦後昭和 25 年から 29 年にかけて，技術合理 化のために投資された金額の中，採鉱部門全投資額の 63 \%に達していることからも伺い知ることが出来る。

この内, 坑内運搬では巻上機購入費及び立坑開さく費 を含んだ立坑関倸の費用が首位を占め, 次いで鉄製鉱車, 運搬用機関車類，ローダーの順になつている。

昭和10年頃の鉱山の運搬状況は, 切羽運搬はほとんど すべての場合鉱車への手積, 或いは漏斗による積込で行 われ，各水平坑道は手押運搬が主体をなし，レベル以上 は坑井に投込まれ、レベル以下は立坑或いは斜坑により 通洞レベルに集められた。通洞レベルもまた手押運搬が 行われ, 手押の限界を超えると小型機関車及びエンドレ ス運搬が用いられるとともに，今日では見ることの出来 ない馬匹運搬が行われていた。

それが昭和25年頃から急速に（勿論それ以前にも用い られてはいたが) 機械化が発達し, 坑道掘進にはローダ 一が，採掘には主としてスクレーパが，主要運搬坑道に は各種運搬機械が採用され，これ等を有効に運用するた めに，大型の鉱車が使用され，集約坑井が設けられ，ま た運搬系統を単純化するために立坑, 斜坑, 水平坑道等 が開さくされて来た。

運搬機械, 積込機械及び運搬系統の切替にはそれぞれ

密接な関係がありこれを分類して考えるのは不適当か も知れないが, これを整理上, 以上の 3 つ分類して, 以下順を追つて 25 年間を回顧してみる。

\section{2. 積込機械}

積込機としてはローダーとスクレーパがあげられる。 $2 \cdot 1$ ローダー 昭和11年 9 月足尾銅山に Eimco 11, 1 台が入荷され, 昭和12年田老鉱山に Eimco 11, 1 台, 佐渡鉱山に Eimco $12 \mathrm{~B} ， 1$ 台が使用された。昭和13年 初为て太空機械が “太空” 98型ローダーを製作し, これ を佐渡鉱山に 4 台納入している。昭和14年にはローダー が普及し, 田老鉱山( 1 台), 尾平鉱山( 1 台), 椢原鉱山 (4 台), 鴻之舞鉱山( 5 台)で使用し, 同年(紀元 2600 年) に98型の改良型である600型を手稲鉱山 ( 2 台) で使用し ている。以後逐次ローダーの使用範囲を広め, 昭和 22 年 116 台, 昭和 27 年 132 台, 昭和 32 年 425 台になつている。 ローダーも種々改良され, 大型化へ, 小型化へと進んだ。 このローダーはジャックレッグ，バッテリロコとコンビ， になつて昭和28年頃からいわゆる one shift one round 掘進法を生み, 坑道の急速掘進を可能にしている。

$2 \cdot 2$ スクレーパ スクレーパの使用は比較的㧍そく, 昭和24年 G.H.Q. の H. Beashings の示唆を受け, 神 岡鉱山が鉱石運搬用にスクレーパを使用し，鉱石の $40 \%$ を取扱つて成功した。また同年松尾鉱山でも坑内積込用 として成功している。松尾鉱山では昭和25年にスクレー パの台数を増加し，出鉱の $50 \%$ ，充填用採土および搔込 の $100 \%$ を取扱つた。以後スクレーパの使用は急激汇普 及している。昭和 25 年, 27 年, 32 年の在籍数を見ると 5 台, 48台, 404 台となつている。昭和 32 年の馬力別台数 は, 10円未満196台, 10〜20円107台, 20〜40H80台，40 〜100H21台となって, 20H以下が非常に多い。

脈状鉱床に打ける採鉱切羽 (Cut \& fill) には $10 \mathrm{H}$ 以 下の空気動が多く用いられ，塊状鉱床では大型が使用さ れている。切羽の条件が許すならば，出来るだけ大型の ものが能率は良いが，採鉱切羽使用する場合には移設 の問題で小型化する傾向がある。しかし昭和 28 年豊羽鉱 山でスクレーパにリモートコントロールを使用し, 昭和 32年柵原および対州鉱山で, 昭和33年河山鉱山でも使用 されるようになつてから大型化する傾向をもつようにな つた。

採掘部門で述べられていると思うが，サブレベルスト 一ピングの場合, 大型のローダー（昭和33年赤金鉱山 Eimco 630）も大型スクレーパ（昭和30年釜石鉱山）と 同様にドローポイントに使用されている。

神岡鉣山におけるローダー，スクレーパ，手積の運搬 経費注第 9 表のようである。

ローダー，スクレーパともに今後は大いに普及するも のと思われる。 